\title{
Development of Defensive Training Futsal Model University of Suryakancana
}

\author{
Muslimin $^{1, *}$, Muhamad Syamsul Taufik², Eneng Fitri Amalia ${ }^{2}$ \\ ${ }^{1}$ Sport Education Program Study, Faculty of Teacher and Training, Universitas Bina Darma, Palembang, Indonesia \\ ${ }^{2}$ Physical Education of Health and Recreation, Faculty of Teacher and Education, University of Suryakancana, Indonesia
}

Received September 22, 2020; Revised February 19, 2021; Accepted February 25, 2021

\begin{abstract}
Cite This Paper in the following Citation Styles
(a): [1] Muslimin, Muhamad Syamsul Taufik, Eneng Fitri Amalia, "Development of Defensive Training Futsal Model University of Suryakancana," International Journal of Human Movement and Sports Sciences, Vol. 9, No. 2, pp. 236-241, 2021. DOI: 10.13189/saj.2021.090211.
\end{abstract}

(b): Muslimin, Muhamad Syamsul Taufik, Eneng Fitri Amalia (2021). Development of Defensive Training Futsal Model University of Suryakancana. International Journal of Human Movement and Sports Sciences, 9(2), 236-241. DOI: 10.13189/saj.2021.090211.

Copyright $\odot 2021$ by authors, all rights reserved. Authors agree that this article remains permanently open access under the terms of the Creative Commons Attribution License 4.0 International License

\begin{abstract}
This research aims to find out use the development in depth training model at Suryakancana University. In addition, research and development were conducted to obtain in depth information about the development and application of training models, to find out and effectiveness, efficiency of the models made, and to increase the curiosity and motivation of athletes in practicing can deepen the exercise. This research and method development used applied for the Research \& Development (R \& D) of Borg and Gall. The method subjects in this research and development were the futsal players the University of Suryakancana. The effectiveness tests that the average value of the game results in futsal before given the training model is as much as 7.0 times and after given the treatment with the model of futsal survival exercise result in 8.4 times the average, which means that there is an increase in the results of the game futsal defending. The model uses the Survival game $0.00<0.05$ with an equivalent significance to 0.05 then $\mathrm{H} 0$ rejected. Based on the information can be concluded that the defensive exercise Model of the University of Suryakancana Futsal game can be applied effectively and efficiently in order to improve the defensive of playing futsal.
\end{abstract}

Keywords Defensive Training, Development, Futsal

\section{Introduction}

Humans basically have limited abilities, 2 object physical skills and psychic. Because of that limitation, people often experience failures. Failures weather it's occur good or bad in physical activities such as in exercising. We play sports, bad or good, occasionally or with intensity, usually we play it with passion. Instead, we exercise, or participate in physical activity, and it is very rarely portrayed as a passion. Another important shift may be that researchers begin to use a variety of methodologies and larger methods, e.g. the growth of Futsal is not only limited to the indoor version, but also to the outdoor. The interest in the outdoor version increased and the company produced the appropriate equipment [1] phenomenology, which emphasizes the importance of individual subjective experiences, and attempts to form research questions based on the concrete reality that is quickened from a phenomenon rather than a theoretical description. These factors need to be improved through training, essential to support performance when in the field. In fact, our early ancestors relied on physical endurance, agility, balance, core strength, proprioseptive consciousness, coordination neuromuskule, and other functional fitness attributes to eat and live.

These activities can be done well in a health-enhancing manner such as physical exercise, if relevant muscle groups are involved, the intensity is sufficient, and the recovery is appropriate. However, in this context, it is important to recognize that in fact not all physical 
activities are correlated with good health [2]. Physical activity seems to bring a long-term beneficial effect on the adiposity and markers of selected cardiovascular health [3] The development of the era affects the emergence of new sports, including futsal. [4]"futbal de Sala has grown into a multi-million Euro marketplace where the pressure to achieve success is high" This is very interesting according to [5]because people who do not have enough time during the day to play futsal can accommodate his desire to play futsal at night in the room that has been given a light fixture as a lighting tool. Futsal Sport can develop in big cities in Indonesia even in the remote areas and recently futsal is getting more and more popular among parents, students, women, men and the state officials. According to [6] Futsal Sport that is played by two opposing teams can be played by anyone, weather children, young and old. [7]No wonder if a futsal player is technically better than the conventional Football players, futsal is more concern to the skills. Because according to [8]"Futsal is 5-a-side indoor football with unlimited number of players' substitutions in which game dynamics require that coaches constantly adjust behaviour of their own team according to the opposite team in a short time. "

Among the activities used in training planning reduced games to provide players with situations that may be more likely to occur during matches.[9]

This is proven by many people who prefer futsal sports compared to other sports and muscle power can be considered one of the important aspects for futsal players[10] The character of the futsal sports game also matches the character of the Asian, and Indonesia is one of it. This is in accourdance with a view [11]"The Similarity of information that guides action is what promotes skill transfer between tasks "the state of Indonesia should be accomplished in the futsal sport because if the review of the posture is not much different from the futsal athletes from other Asian countries. According to [12] it takes the basic technique of mastering the perfect futsal play. In achieving an achievement must have skills and ability to play futsal sports, one of which is good basic technical mastery of futsal, [13] motion error occurs because of incomplete motion memory, incompleteness of the basic skills will result in error and forgetting pattern of the game.

Based on the explanation above the researchers conducted an interview about futsal training in ukm (student activity Unit) Futsal Suryakancana, the result interview with the head of the coach UKM (student activity Unit) Futsal Suryakancana showed that the material provided while performing defend exercise the difficulties are experienced during by students the conduct of the defend exercise, in getting the ball, and there is no seriousness during exercise due to lack of model exercise. Student response to the exercise of survival is very lacking. It can be seen from some games that the final result is always lost in the last 8 major rounds in the
Rector Cup Pakuan 2019 that the University of the Surykancana lost in the 8th round with a bad defensive pattern where the opponent can make many goal out to the futsal goal of the University of Suryakancana. The results of the interview with the trainer while training using force to several players and to be an example for the players of the unit UKM Futsal Collage student of the University of Suryakancana. Researchers also asked about the development of a defensive exercise model with the form of modules in the trainer as well as the player whether to be able to improve the survival ability.

\section{Materials and Methods}

The approach used in this study is a qualitative and quantitative approach, Research and Development is a research that seeks to develop a particular product in accordance with the needs of the recent community, especially in the scope of training [14] The subjects of this study were futsal extracurricular students at Suryakancana University, as many as 30 students. Data collection instruments in this study used observation techniques, interviews and open-ended questionnaires. The data analysis technique used in this study is a qualitative and quantitative descriptive analysis technique in the form of a percentage. The time in research and development research starts from December to February 2020 The target in this research that researchers do is intended for adolescents (students) and adults. The subject taking technique applied in this research is purposive sampling which is also known as consideration sampling or based on certain considerations. The approach used in this research is an approach using the Research \& Development (R \& D) model of Borg and Gall which consists of ten steps or can also be described in the form of a developmental stage scheme as shown below.

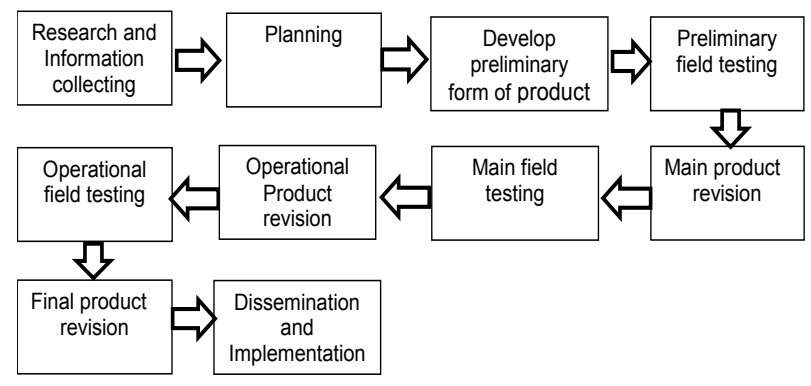

Figure 1. Instructional Design R \& Discourses: Walter R. Borg and Meredith D. Gall, Educational Research: An Introduction, 4th Edition.[15]

The Research instrument uses test results in the gaming capabilities in the form of an objectively enduring assessment, data analysis techniques used in the development study of the model for the improvement of Futsal Laboratory of the University of Suryakancana 
using quantitative and qualitative descriptive by Borr and gall stage and effective test using T test using SPSS 20.

\section{Research Results}

\subsection{Analysis Results}

The skill Training Model which is going to be made is the result from the problems found by the researcher in the field through the process of observation and interviews through the questionnaire given by researchers to the coaches. To the results of the interviews processed and described by the research to provide solutions by developing models of futsal skills training, the results of the data that researcher has gathered through interviews and polls to 30 students are then processed and described in the research formulation conducted to the students from December to February 2019, where the need for the analysis of the form of poll in university. The analysis of these needs can be noted that: (1). Students are very interested in futsal training activities. (2). Students are bored with the variety of training skills provided. (3). Students agree to develop a model of Defense training. (4) The futsal coach needs a Defense training model. (5). The coach needs media references in the form of electronic and non-electronic books.

\subsection{Planning Model Futsal Defensive Exercise}

Previous Study results or the subsequent field findings are described and analyzed so that these results are descriptive and analytical, referring to the previous study objectives. The Next step is to make the initial product in the form of Model development series that can be used as a guideline or guidance to maximize the result of the basic technical product futsal is poured in the model of exercise. The development of the training model is expected to be a systematic and logically developed product, so that this product has the effectiveness and efficiency that is worth using. In the manufacture making of products developed by researcher, researchers must consult to the experts in order to produce the perfect product.

\subsection{Feasibility Model}

After the researchers perform the data collection and the drafting of the futsal model exercise, the next step is, conducting expert tests obtain the feasibility or validity of models made with the direct assessment of the in order to experts. Researchers are able to ask 3 experts to assess the feasibility of a defensive exercise model, where 3 members are professionals as lecturers and sports trainers. (Widiastuti, Guntur, and Raja Dimas).

\subsection{Small Group Trial Results}

The Development of this defensive futsal exercise model that researcher made after being evaluated by the experts, Based on the evaluation of small group tests with 15 Data subjects. The test result of this group resulted from a field note (filed note) of the model test results. The result of small group trials was made material to futsal model training defensive. By using treeament for one week and the results are very effective and efficient. The Result of the respondent being performed on a small group player is the second evaluation, of the previous experts. Furthermore, the result is revised.

\subsection{Product Revision}

Input from Questionnaire results and field notes on small group tests were used to revise the product. This was done for the improvement of the model that has been perceived and experienced for the subject for the next group test. Research conducted by researcher can be concluded as follows:1. The Whole variety of model training Model Futsal training models Suryakancana, which should be considered the training model starts from the easy level until is difficult to improve the child's skills model. 2. There should be an example of movement in advance on each model of the exercise so that it is easy to understand the series of raids..3. At the time of applying exercise model in field athletes less focused so the trainer's task should often monitor for the goal of exercise and exercise targets achieved.

\subsection{Big Group Trial Results}

After the results of the development of skills training for college student athletes have been tested on a small scale and have been revised, the next step is to carry out group trials on a large scale. The treatment is carried out within 1 month, 1 week starting from December to January 2019 with 16 meetings, Monday, Tuesday, and Thursday 3 times a week. During the study, the treatment group was given 10 models of Futsal defensive from the Suryakancana Futsal University at each meeting. Before giving treatment, the research subject in the preliminary test used a cognitive test instrument of defensive games in the futsal game of the research subject before and after treatment.

\subsection{Revised Finaliasai Product}

Result the conclusion of the field trials is the last base to repair and improve the new product models of sports and construction of Futsal in Suryakancana University response results from players after performing exercises directly given input evaluation improvement of the model development. Based on the results of small group trials that have been evaluated by experts, the researchers then revised the initial product and obtained 36 Suryakancana University Futsal training defensive Model to be used in 
large group trials. The next step after the model undergone a second stage revision by the experts, is testing the product to the large group by using the subject of 30 students phase per each faculty/Prodi different the next step after the model has undergone two revision of the expert and small group trials and large groups then continued by testing the product to use research subjects as much as 50 subject evaluation research at this stage is the end evaluation of the model of the Futsal defending model exercise after the repairing to the input of the field test, model product is considered to be disseminated or applied.

\subsection{Test Effectiveness}

Analysis of data to test hypotheses on this study used parametric statistical analysis, namely test- $T$ (paired T-Test).

Table 1.1. Results Paired Samples Statistics (Pre Test), and after-Treatment (Post Test) game Futsal Survival

Paired Samples Statistics

\begin{tabular}{cccccc}
\hline & Mean & $\mathrm{N}$ & $\begin{array}{c}\text { Std. } \\
\text { Deviation }\end{array}$ & $\begin{array}{c}\text { Std. Error } \\
\text { Mean }\end{array}$ \\
\hline Pair & Pre_Test & 7.0600 & 30 & 1.51738 & .21459 \\
\cline { 2 - 6 } 1 & Post_Test & 8.4400 & 30 & 1.21487 & .17181 \\
\hline
\end{tabular}

Based on the table above the average value of the game results in futsal before being given the training model is much as 7.0 times and after being given treatment with the Model of futsal defending exercise is 8.4 times the average, which means that there is an increase in the results of the game futsal defending.

Table 1.2. Results Paired Samples Correlations (Pre Test) and after-Treatment (Post Test) Futsal survival game It increases.

\begin{tabular}{ccccc}
\multicolumn{5}{c}{ Paired Samples Correlations } \\
\hline & N & Correlation & Sig. \\
\hline Pair 1 & Pre_Test \& Post_Test & 30 & .694 & .000 \\
\hline
\end{tabular}

Models use the Survival game $0.00<0.05$ with an equivalent significance of 0.05 then $\mathrm{H} 0$ is rejected. Based on the information can be concluded the defensive exercise Model of the University of Suryakancana Futsal game that can be applied effectively and efficiently so as to improve the skills of playing futsal. Suryakancana University Futsal Training

\subsection{Product Revisions}

The revision of this product can be done, if it is used in the wider model trials there are shortcomings and weaknesses. Based on that, the developed model will be repaired or refined to optimize its use. Bulk product manufacturing products that have been declared effective in several tests, large group results and effective test results then this training model product can be applied to the public.

\subsection{Bulk Product Creation}

This product is ultimately the model manual for the training of the futsal training, which is distributed to the players and coaches in the University of Suryakancana and contributions to the District Cianjur.

\section{Discussion}

Futsal Model for students of the student activity Unit Suryakancana was created by researchers to assist the trainer or teacher in varying skill exercises, improving the skills of senior age athletes with a donation of persisted formation as a reference exercise. This Model is made on the basis of children's needs especially in futsal student Unit. This product after being examined about some of the disadvantages that need improvement then can be delivered some advantages of this product, among others: can improve the skills of senior athletes, futsal exercise Model survives more effectively and efficiently. Model used very varied that can increase the level of students ' enthusiasm in practice, senior athletes can feel the comfort and security in the process of futsal training and can use his test, this Model can be a Turbo booster motivation Student collage for physical care, as a reference exercise in the school which can help teachers/coaches in training students in campus, as well as donations for science in particular physical education.

Then the explanation According to [16]the model is a planning design that is used to describe or explain a process of activities in order to fulfill the expected goals, because according to [17] "Decision-making refers to the human brain's ability to perceive relevant information "because of that the trainer believes that it is very appropriate and in line, with the development of the model of the Endurance Training is very helpful for the Futsal defense exercise in UKM (student activity unit) during training and makes it easy for students to communicate well with the trainer and is useful and can avoid exercise survive on futsal from boredom and so that the exercise vocation is more intervesting. Because there are reviews of defensive training, the researchers package it through the exercise module book and the video results of the development of the same model with the view. According to [18] "There are two other major methodologies which have shown promises in relating training load to performance." Expectations desired by UKM Students (futsal University Student Activity Unit of Suryakancana with the development of a survival training model will be effective and efficient quickly by using media modules 
and videos to facilitate the training process, because the same is raised by [19]The selection of futsal players and clear training programs also support the achievements of sports achievements. Then in the study there are two general objectives in this study are what you want to know in how important the futsal survival training model of the university in Suryakancana constraints and what support is found in the development of the futsal training model of the University of Suryakancana. Previous research emphasized that 4 weekly futsal training sessions over a 4 week period have a significant effect[20].The limitations of research products are made as perfect as possible by the ability of PEneliti, but if in this research there are still many limitations that must be recognized and presented as an ingredient for consideration in generalizing the results of the research achieved. The limitations are as follows: When researchers do the good field trials are done on the scope of the longer scope, the product is made far from the word perfect and the facilities and infrastructure is insufficient and limited, explanation in the training picture game defensive less perfect. Effectivity model of development in exercise skill and technic[21]. Our results approve the Yo-Yo intermittent recovery level 1 (Yo-Yo IR1) test as a valid and reliable test to monitor improvements or decrements of soccer physiological and anthropometrical training concept game demands. It can be concluded in this study as simple and valid data to predict the excess of body fat index on the request aerobic fitness claims for demanding soccer top player profile[22]. There are differences between the two training methods in improving VO2Max players. It was found that using effective soccer training methods had a difference of 12,963 to conventional training in improving VO2Maxplayers[23]. The results of this study indicate that fast linear speed can positively impact on RSTT performance whilst reduced aerobic endurance capabilities may negatively influence RSTT performance in female international footballers[24]

\section{Conclusion}

Based on the data obtained, field trials results and discussion of research results: (1) with the development of model futsal exercises Suryakancana University can practice effectively and efficient (2) with the development of model futsal training of Suryakancana University can increase the passion in practicing physical aspects and skills.

\section{REFERENCES}

[1] Keshvari B and Senner V 2015 Comparison of shoe-surface tractions on various playing surfaces in futsal Procedia Eng. 112 267-72

[2] Sjøgaard G, Christensen J R, Justesen J B, Murray M, Dalager T, Fredslund G H and Søgaard K 2016 Exercise is more than medicine: The working age population's well-being and productivity J. Sport Heal. Sci. 5 159-65

[3] Cheng S and Mao L 2016 Physical activity continuum throughout the lifespan: Is exercise medicine or what? $J$. Sport Heal. Sci. 5 127-8

[4] Yiannaki C, Carling C, Collins D, Yiannaki C, Carling C, Collins D, Yiannaki C and Carling C 2018 Futsal as a potential talent development modality for soccer - a quantitative assessment of high- level soccer coach and player perceptions assessment of high-level soccer coach and player perceptions Sci. Med. Footb. 0 1-10

[5] Silva W R da, Freitas K, de Carvalho H, Ferrari E, Vieira M and Cardoso F L 2018 Satisfaction with life and subjective social status in athletes of indoor soccer and soccer Rev. Bras. Ciencias do Esporte 40 374-80

[6] de Oliveira R S, Borin J P, Fernandes P T, Uchida M C and Borges T de O 2019 Description of 18 weeks integrated training on the displacement speed in Brazilian futsal players Rev. Bras. Ciencias do Esporte 41 308-13

[7] Taylor P, Greig M and Greig M 2009 European Journal of Sport Science The influence of soccer-specific activity on the kinematics of an agility sprint $37-41$

[8] Almeida J, Sarmento H, Kelly S, Travassos B, Almeida J, Sarmento H, Kelly S, Travassos B and Kelly S 2019 Coach decision-making in Futsal : from preparation to competition Coach decision-making in Futsal: from preparation to competition Int. J. Perform. Anal. Sport 0 1-13

[9] Müller E S, da Costa I T and Garganta J 2018 Tactical analysis in futsal: comparative study of performance by players from four age levels Rev. Bras. Ciencias do Esporte $40248-56$

[10] Dal Pupo J, Detanico D, Arins F B, Nascimento Salvador P C, Guglielmo L G A and dos Santos S G 2017 Capacidade de sprints repetidos e níveis de potência muscular em jogadores de futsal das categorias sub 15 e sub 17 Rev. Bras. Ciencias do Esporte 39 73-8

[11] Oppici L, Panchuk D, Serpiello F R, Farrow D, Oppici L, Panchuk D, Serpiello F R, Farrow D, Oppici L and Panchuk D 2018 Futsal task constraints promote transfer of passing skill to soccer task constraints constraints Eur. J. Sport Sci. 0 $1-8$

[12] Beltrão de Matos J A 2008 Acceleration capacity in futsal and soccer players Fit. Perform. J. 7 224-8

[13] Caglayan A, Erdem K, Colak V and Ozbar N 2018 The Effects of Trainings with Futsal Ball on Dribbling and Passing Skills on Youth Soccer Players Int. J. Appl. Exerc. Physiol. 7 2322-3537

[14] Barcelos R P, Tocchetto G L, Lima F D, Stefanello S T, Rodrigues H F M, Sangoi M B, Moresco R N, Royes L F F, Soares F A A and Bresciani G 2017 Functional and biochemical adaptations of elite level futsal players from Brazil along a training season Med. 53 285-93

[15] Gall M D, Gall J P and Borg W R 2003 
Epdf.Pub Educational-Research-an-Introduction-7Th-Editi on.Pdf

[16] Kao S F, Hsieh M H and Lee P L 2017 Coaching competency and trust in coach in sport teams Int. J. Sport. Sci. Coach. 12 319-27

[17] Gantois P, Elisa M, Ferreira C, Lima-junior D De, Nakamura Y, Batista G R, Fonseca F S and De L 2019 Effects of mental fatigue on passing decision- making performance in professional soccer athletes Eur. J. Sport Sci. 0 1-21

[18] Mitchell L J G, Rattray B, Fowlie J, Saunders P U and David B 2020 The impact of different training load quantification and modelling methodologies on performance predictions in elite swimmers Eur. J. Sport Sci. 0 1-29

[19] Nogueira F C d. A, de Freitas V H, Nogueira R A, Miloski B, Werneck F Z and Bara-Filho M G 2018 Mejora del rendimiento físico, perfil hormonal, balance estrés-recuperación y aumento del daño muscular basado en la planificación específica de pretemporada en el fútbol sala Rev. Andaluza Med. del Deport. 11 63-8

[20] Rezaimanesh D, Amiri-Farsani P and Saidian S 2011 The effect of a 4 week plyometric training period on lower body muscle EMG changes in futsal players Procedia - Soc. Behav. Sci. 15 3138-42
[21] Muslimin, Moch. Asmawi, Samsudin, Firmansyah Dlish, James Tangkudung, Aprizal Fikri , Destriana , "Model Development of Digital Based Volleyball under Service Skills Instruments," International Journal of Human Movement and Sports Sciences, Vol. 8, No. 6A, pp. 42 - 46, 2020. DOI: $10.13189 /$ saj.2020.080707.

[22] Mime Mokhtar , Zerf Mohammed , Hadjar Kherfane Mohamed, Beboucha Wahib, "Maximal Oxygen Levels as an Incremental Exercise to Optimise Individual Training Prescription with the Aim of Rectifying Weaknesses of Elite Algerian Soccer," International Journal of Human Movement and Sports Sciences, Vol. 7, No. 4, pp. 74 - 80, 2019. DOI: 10.13189/saj.2019.070402.

[23] Ridho Bahtra, Moch. Asmawi, Widiastuti, Firmansyah Dlis , "Improved $\mathrm{VO}_{2} \mathrm{Max}$ : The Effectiveness of Basic Soccer Training at a Young Age," International Journal of Human Movement and Sports Sciences, Vol. 8, No. 3, pp. 97 - 102, 2020. DOI: $10.13189 /$ saj.2020.080304.

[24] Brian Doyle, Declan Browne, Dan Horan, "The Relationship of Aerobic Endurance and Linear Speed on Repeat Sprint Ability Performance in Female International Footballers," International Journal of Human Movement and Sports Sciences, Vol. 8, No. 4, pp. 147 - 153, 2020. DOI: 10.13189/saj.2020.080407. 